\title{
FAKTOR-FAKTOR YANG MEMPENGARUHI HASIL BELAJAR SISWA PADA PEMBELAJARAN PRAKTIK KELISTRIKAN OTOMOTIF SMK DI KOTA YOGYAKARTA
}

\author{
Valiant Lukad Perdana Sutrisno \\ FKIP Universitas Sebelas Maret Surakarta \\ valiantlps@gmail.com \\ Budi Tri Siswanto \\ Universitas Negeri Yogyakarta \\ budi_ts@uny.ac.id
}

\begin{abstract}
Abstrak
Penelitian ini bertujuan untuk mengetahui pengaruh dari persepsi penguasaan metode mengajar praktik guru, media pembelajaran yang digunakan guru, dan motivasi belajar siswa terhadap hasil belajar siswa pada pembelajaran praktik kelistrikan otomotif SMK keahlian TKR di Kota Yogyakarta. Jenis penelitian ini adalah ex-post facto. Populasi penelitian ini adalah seluruh siswa kelas XII pada kompetensi TKR di SMK Kota Yogyakarta yang berjumlah 565 siswa. Sampel sejumlah 185 siswa ditentukan dengan teknik proportional random sampling. Pengambilan data variabel bebas menggunakan angket dengan skala Likert dan Rating Scale. Data variabel terikat dikumpulkan menggunakan dokumentasi. Analisis data menggunakan analisis regresi linier berganda. Hasil penelitian menunjukkan empat temuan ytiu: (1) terdapat pengaruh yang signifikan persepsi penguasaan metode mengajar praktik guru terhadap hasil belajar praktik kelistrikan otomotif; (2) terdapat pengaruh yang signifikan dari persepsi media pembelajaran terhadap hasil belajar pembelajaran praktik kelistrikan otomotif; (3)terdapat pengaruh yang signifikan dari motivasi belajar siswa terhadap hasil belajar pembelajaran praktik kelistrikan otomotif; (4) terdapat pengaruh yang signifikan dari persepsi penguasaan metode mengajar praktik guru, persepsi media pembelajaran, dan motivasi belajar siswa secara bersama-sama terhadap hasil belajar pembelajaran praktik kelistrikan otomotif.
\end{abstract}

Kata kunci: persepsi, metode mengajar praktik, motivasi belajar, media pembelajaran, hasil belajar, pembelajaran praktik, kelistrikan otomotif

\section{FACTORS AFFECTING THE LEARNING OUTCOMES IN THE TEACHING AND LEARNING OF AUTOMOTIVE ELECTRICAL PRACTICE OF SMK IN YOGYAKARTA CITY}

\begin{abstract}
The research aimed to reveal the effect of perceptions of teachers' mastery of practice teaching methods, instructional media used by teachers, and students' motivation on the learning outcomes in the teaching of automotive electrical practice of SMK of TKR expertise in Yogyakarta City. The research was ex-post facto research. The population was all grade XII students of SMK light vehicle enginering expertise in Yogyakarta City totalling 565 students. A sample of 185 students was established using the proportional random sampling technique. The data of the independent variable were collected using a questionnaire with Likert scale and Rating scale. The data of the dependent variable were collected using documentation. The data were analyzed using the multiple regression analysis. The research revealed four findings. (1) There was a significant effect of perceptions of teachers' mastery of practice teaching methods on the learning outcomes in the teaching of automotive electrical practice; (2) There was a significant effect of instructional media on the learning outcomes in the teaching of automotive electrical practice; (3) There was a significant effect of the students' motivation on the learning outcomes in the teaching of automotive electrical practice; (4) There was a significant effect of perceptions on teachers' mastery of practical teaching methods, perceptions on instructional media, and students' motivation collectively on the learning outcomes in the teaching of automotive electrical practice.
\end{abstract}

Keywords: perceptions, practice teaching method, student's motivation, instructional media, learning outcomes, teaching practice, automotive electrics 



\section{PENDAHULUAN}

Perkembangan teknologi yang pesat pada masa kini salah satunya dapat dilihat melalui perkembangan teknologi di dunia industri otomotif. Di Indonesia, pertumbuhan industrinya pun kian merajai jika dibandingkan dengan jenis industri lainnya. Pesatnya perkembangan teknologi otomotif tentu saja akan diiringi dengan meningkatnya kebutuhan tenaga kerja di bidang otomotif. Terkait hal itu, pemerintah sudah melakukan antisipasi salah satunya dengan membuat Rencana Strategis (Renstra) yang salah kebijakannya adalah membalik rasio peserta didik Sekolah Menengah Kejuruan (SMK) dibanding (Sekolah Menengah Atas) SMA dari 30:70 pada tahun 2004 menjadi 67:33 pada tahun 2014. Perubahan rasio tersebut tentu saja akan menuntut sebuah transformasi secara menyeluruh di dunia pendidikan.

Transformasi di dunia pendidikan yang direncanakan tentu saja haruslah memenuhi kaidah prinsip link and match yang menjadi inti dari keberhasilan penerapan pendidikan kejuruan. Melalui penerapan konsep ini tidak hanya secara masif memicu transformasi sarana dan prasarana pendidikan namun juga menuntut perubahan pada guru sebagai aktor utama yang menjalankan pembelajaran di sekolah. Fakta yang terjadi di Indonesia sebagai salah satu negara berkembang harus menghadapi beberapa hambatan untuk mewujudkan pendidikan kejuruan yang ideal berdasarkan konsep link and match seperti kekurangan guru berkualitas, sulit memenuhi biaya operasional yang tinggi, peralatan praktik yang serba kurang, ketidakjelasan kurikulum, dan masalah pemeliharaan serta perbaikan peralatan (Bukit, 2014).

Permasalahan yang dihadapi pendidikan kejuruan di Indonesia bahkan lebih spesifik pada beberapa hal potensial yang idealnya dapat menjadi solusi bagi tingginya pengangguran namun realitanya justru potensi tersebut menjadi permasalahan yang belum ditemukan pemecahannya. Industri otomotif yang kian giat mengembangkan teknologi sistem elektronik justru di SMK Keahlian TKR (Teknik Kendaraan Ringan) hasil belajar pada kelistrikan otomotif khususnya pada teknologi kelistrikan terbaru seperti pengapian elektronik dan injeksi bensin grafik nilainya selalu mengalami penurunan. Hasil belajar praktik kelistrikan otomotif rendah ini tidak hanya dialami oleh Pusat Pelatihan seperti di VEDC Malang saja, namun pada SMK di Kota Yogyakarta juga mengalami permasalahan dengan hasil belajar praktik kelistrikan otomotif yang selalu rendah dan seringkali menjadi 'ranjau' ketidaklulusan para siswa.

Kajian teori dan hasil penelitian yang relevan menunjukkan bahwa hasil belajar merupakan gambaran efektivitas pembelajaran. Hasil belajar praktik kelistrikan otomotif yang selalu rendah menunjukkan gambaran keberhasilan pembelajaran praktik yang terjadi di SMK Keahlian TKR di Kota Yogyakarta yang masih bermasalah. Permasalahan-permasalahan yang selama ini diduga menyebabkan hasil belajar praktik selalu rendah ini diantaranya (1) motivasi siswa belajar yang masih rendah; (2) persepsi siswa mengenai kelistrikan itu memiliki tingkat bahaya yang tinggi; (3) media pembelajaran kelistrikan yang terbatas; (4) sarana dan pra sarana bengkel yang tidak memenuhi syarat untuk melaksanakan praktikum; (5) latar belakang pendidikan siswa yang berbeda-beda; dan (6) guru belum menemukan cara yang tepat dalam membangun pemahaman awal siswa dalam mempelajari kelistrikan otomotif.

Fokus penelitian jika ditinjau dari empat elemen syarat terjadinya pembelajaran ini adalah permasalahan metode mengajar praktik yang digunakan oleh guru, masalah motivasi belajar siswa, dan media pembelajaran yang digunakan sebagai pendamping selama pembelajaran praktik berlangsung.

Pendidikan kejuruan merupakan jenis pendidikan yang memiliki karakteristiknya tersendiri serta memiliki tujuan tertentu yang menjadi landasan penyelenggaraannya. Prosser dan Quigley (1950, p.216) menyatakan bahwa esensi dari pendidikan kejuruan adalah menerapkan suatu pola pembiasaan berpikir dan berlatih yang dilakukan secara berulang-ulang dan berkelanjutan. Pendidikan kejuruan sangat mengutamakan bagaimana pembentukan pola pikir dan keterampilan yang diajarkan kepada peserta didiknya semirip mungkin dengan kondisi lingkungan kerja yang akan dihadapinya kelak. Ini artinya pendidikan kejuruan adalah pendidikan dengan maksud khusus untuk mendidik peserta didik agar memiliki keterampilan spesifik tertentu yang dapat digunakannya pada saat bekerja kelak. 
Spesifiknya keterampilan yang diajarkan di pendidikan kejuruan juga diungkapkan oleh Pavlova (2009, p.7) bahwa pendidikan kejuruan adalah suatu pendidikan yang menyediakan pelatihan keterampilan secara spesifik pada bidang tertentu untuk mencapai kompetensi keterampilan yang diinginkan yang bersumber dari pendidik dengan tujuan untuk mengembangkan pemahaman mengenai dunia industri tertentu yang berisi keterampilan, keahlian dan trik tertentu. Ini artinya pendidikan kejuruan merupakan pendidikan yang memang didesain secara khusus mengacu pada dunia kerja yang menjadi tujuan bagi peserta didik tertentu yang memiliki tujuan untuk berkarir di bidang tertentu yang memerlukan keahlian yang spesifik.

Dalam dunia pendidikan kejuruan terdapat kegiatan utama yang menjadi inti dari pendidikan yaitu pembelajaran. Pembelajaran merupakan kegiatan yang sengaja diadakan dengan rancangan tertentu untuk memudahkan kegiatan belajar. Diungkapkan Gagne dalam Pribadi (2010, p.9) bahwa pembelajaran adalah serangkaian aktivitas yang sengaja diciptakan dengan maksud untuk memudahkan terjadinya proses belajar. Artinya, pembelajaran adalah merupakan kegiatan yang secara sistematis dirancang dan dilaksanakan dengan prosedur tertentu untuk melakukan pendekatan sebaik mungkin untuk tercapainya tujuan belajar yang telah ditetapkan.

Pembelajaran setidaknya melibatkan 4 elemen yang menjadi syarat terjadi pembelajaran. Sistem Pendidikan Nasional dalam UU RI No. 20 Tahun 2003 (Depdiknas, 2003) mendefinisikan mengenai pembelajaran yaitu, pembelajaran adalah proses interaksi peserta didik dengan pendidik dan sumber belajar pada suatu lingkungan belajar. Berdasarkan hal tersebut maka untuk meningkatkan kualitas pembelajaran di sekolah idealnya keempat elemen itulah yang seharusnya menjadi fokus perbaikan dan pengembangan.

Dalam pembelajaran idealnya akan selalu terjadi interaksi antara guru dengan siswa. Karena guru dan siswa merupakan dua elemen yang berada pada lingkungan belajar dan memanfaatkan sumber belajar. Terkait interaksi antara guru dengan siswa, persepsi siswa terhadap kemampuan guru dalam mengajar dan menggunakan sumber belajar seperti media pembelajaran dapat dijadikan bahan umpan balik terhadap kualitas mengajar dan kemampuan guru menggunakan media pembelajaran.

Persepsi seperti yang diungkapkan oleh Atkinson, et al. (2010, p.276) adalah bagaimana kita mengintegrasikan sensasi ke dalam percepts objek, dan bagaimana selanjutnya penggunaan percepts itu untuk mengenali dunia. Ini artinya persepsi merupakan titik awal bagi seorang manusia untuk mengenal suatu obyek atau peristiwa yang dihadapinya. Hasil dari mengenal tersebut merupakan dasar bagi manusia untuk bertindak seperti yang diungkapkan Santrock (2012, p.150) yaitu persepsi membuat kita menjalin kontak dengan lingkungan sehingga kita dapat berinteraksi dan beradaptasi terhadapnya. Persepsi dirancang untuk tindakan. Berdasarkan hal tersebut maka dapat disimpulkan persepsi memang menjadi titik awal bagi manusia untuk bertindak dan persepsi juga dapat menggambarkan kondisi terhadap objek atau peristiwa yang dihadapinya.

Guru yang menjadi aktor utama dalam mengelola pembelajaran khususnya dalam pendidikan kejuruan yakni pembelajaran praktik idealnya harus menguasai metode mengajar praktik yang benar, karena pembelajaran praktik memiliki karakteristik tersendiri yang tidak dapat disamakan dengan pembelajaran teori di kelas. Dalam mengajar praktik setidaknya ada 4 tahapan esensial yang harus dikuasai oleh guru seperti yang diungkapkan oleh Leighbody dan Kidd (1966, p.21) yaitu (1) tahap persiapan, (2) tahap presentasi, (3) tahap aplikasi, dan (4) tahap pengujian. Keempat tahapan esensial tersebut haruslah dilaksanakan oleh guru dengan melibatkan siswa secara bersama-sama mulai dari awal sampai akhir pembelajaran praktik.

Dalam melaksanakan keempat tahapan esensial tersebut guru dituntut dapat menerapkan beberapa metode mengajar berbeda yang sesuai dengan masing-masing tahapan. Terkait dengan hal tersebut Westwood (2008, p.56) mengungkapkan bahwa tingkat keefektifan seorang guru adalah guru yang tidak hanya berfokus pada salah satu metode mengajar saja. Ini artinya seorang guru idealnya tidak boleh terpaku hanya pada satu metode mengajar saja karena dalam mengajar seorang guru harus dapat menyesuaikan situasi dan kondisi agar tercipta pembelajaran yang berkualitas. 
Guru dalam aktivitasnya mengajar praktik idealnya memerlukan bantuan dari alat bantu mengajar seperti media pembelajaran yang dapat menunjang keberhasilannya dalam mengajar. Sadiman, et al. (2012, p.7) menyatakan media adalah segala sesuatu yang dapat digunakan untuk menyalurkan pesan dari pengirim ke penerima sehingga dapat merangsang pikiran, perasaan, perhatian dan minat serta perhatian siswa sedemikian rupa sehingga proses belajar terjadi. Penggunaan media dalam pembelajaran tidak terbatas pada penggunaannya dalam proses belajar namun juga memiliki tujuan spesifik yaitu tercapainya belajar yang efektif.

Penggunaan media dalam pembelajaran merupakan sarana penunjang yang dapat meningkatkan efisiensi dan efektivitas keberhasilan pembelajaran seperti yang diungkapkan Smaldino, et al. (2012, p.5) yaitu teknologi dan media yang disesuaikan dan dirancang secara khusus bisa memberi kontribusi bagi pengajaran yang efektif dari seluruh siswa dan bisa membantu mereka meraih potensi tertinggi mereka. Ini artinya media dan teknologi memiliki andil yang kontributif untuk dapat meningkatkan kualitas pengajaran di kelas dan juga dapat membangkitkan potensi terbaik dari siswa. Berdasarkan uraian-uraian di atas maka didapatkan simpulan bahwa media pembelajaran merupakan alat bantu dengan karakteristik tertentu yang bisa disesuaikan tergantung konteks pelajaran yang diinginkan untuk menyampaikan pesan agar tercapai tujuan belajar secara efektif dan efisien.

Metode mengajar praktik guru dan media pembelajaran seperti yang sudah dibahas merupakan dua elemen pembentuk pembelajaran yang tidak akan berfungsi jika tidak ada elemen peserta didik yaitu siswa, karena siswa sebenarnya yang menjadi fokus dalam setiap pembelajaran. Motivasi belajar siswa merupakan salah satu hal yang muncul dalam permasalahan pembelajaran kelistrikan otomotif. Keller (2010, p.3) mengungkapkan bahwa motivasi adalah motivasi secara umum mengacu pada keinginan atau hasrat seseorang, apa yang menjadi pilihan untuk dilakukannya dan terhadap apa dia memutuskan komitmennya. Ini artinya dalam belajar siswa yang memiliki motivasi akan berkomitmen dalam melakukan kegiatan belajarnya sampai dia memperoleh tujuan belajar yang diinginkannya.
Uno (2014, p.23) mengungkapkan motivasi belajar secara lebih spesifik yaitu dorongan internal dan eksternal pada siswasiswa yang sedang belajar untuk mengadakan perubahan tingkah laku, pada umumnya dengan beberapa indikator atau unsur yang mendukung. Dorongan yang ada dalam diri siswa ini akan menyertai siswa tersebut dari awal kegiatan belajarnya sampai siswa tersebut merasa cukup untuk mencapai tujuan belajarnya. Dorongan motivasi tersebut akan sangat mempengaruhi bagaimana siswa tersebut mampu belajar dengan baik. Ini artinya melalui motivasi belajar setiap siswa dapat mengalami peningkatan seperti bekerja dengan lebih efektif dan efisien, mengalami peningkatan dalam ketertarikan untuk sekolah dan mencapai potensi-potensinya secara lebih baik.

Elemen-elemen syarat terjadinya pembelajaran seperti yang diuraikan sebelumnya idealnya dapat menjadi indikator dalam meningkatkan hasil belajar siswa, karena setiap pembelajaran pasti akan menghasilkan hasil belajar. Diungkapkan Djamarah dan Zain (2013, p.2017) yaitu, setiap proses belajar mengajar selalu menghasilkan hasil belajar. Masalah yang dihadapi adalah sampai di tingkat mana prestasi (hasil) belajar yang dicapai. Hal tersebut menggambarkan bahwa yang dapat menjadi fokus bagi pendidik adalah bagaimana mengelola pembelajaran sehingga dapat mencapai tingkat hasil belajar yang diinginkan.

Sudijono (2012, p.32) mengungkapkan hasil belajar merupakan sebuah tindakan evaluasi yang dapat mengungkap aspek proses berpikir (cognitive domain) juga dapat mengungkap aspek kejiwaan lainnya, yaitu aspek nilai atau sikap (affective domain) dan aspek keterampilan (psychomotor domain) yang melekat pada diri setiap individu peserta didik. Ini artinya melalui hasil belajar dapat terungkap secara holistik penggambaran pencapaian siswa setelah melalui pembelajaran. Perwujudan nyata dari hasil belajar siswa di SMK terlihat pada penyelenggaraan Uji Kompetensi Keahlian (UKK) Praktik Kejuruan. UKK Praktik Kejuruan mampu menggambarkan secara holistik tingkat pencapaian siswa setelah pembelajaran karena memiliki enam komponen penilaian yaitu: (1) pengetahuan; (2) persiapan; (3) proses (sistematika \& cara kerja); (4) hasil kerja; (5) sikap kerja; (6) waktu. 
Penelitian ini penting dilakukan agar dunia pendidikan kejuruan khususnya SMK Keahlian TKR dapat sesegera mungkin menemukan faktor permasalahan yang sebenarnya memberikan pengaruh terhadap rendahnya efektivitas pembelajaran praktik yang dilihat melalui hasil belajar praktik kelistrikan otomotif. Memang sudah menjadi rahasia umum di SMK Keahlian TKR bahwa kelistrikan otomotif selalu menjadi 'momok' bagi kebanyakan peserta didik baik karena pelajarannya yang dianggap paling sulit, motivasi belajar yang rendah, sampai pada sarana dan prasarana yang kurang mendukung. Namun, hal tersebut belum pernah dibuktikan secara ilmiah dan diungkapkan oleh data yang faktual. Oleh karena itu melalui penelitian ini diharapkan dapat mengungkap permasalahan tersebut dan dapat membantu dalam menemukan solusi permasalahan tersebut.

\section{METODE PENELITIAN}

Penelitian ini menggunakan pendekatan kuantitatif deskriptif. Ditinjau dari metodenya maka jenis penelitian ini merupakan ex-postfacto. Penelitian dilakukan di SMK Kota Yogyakarta yang memiliki kompetensi keahlian Teknik Kendaraan Ringan tahun pelajaran 2014/2015 yakni SMKN 2, SMKN 3, SMK Muhammadiyah 3, SMK Piri 1, SMK Perindustrian, dan SMK Taman Siswa yang dilakukan pada bulan September 2014 sampai dengan bulan Mei 2015.

Populasi pada penelitian ini adalah para siswa kelas XII Kompetensi Keahlian Teknik Kendaraan Ringan di SMK Kota Yogyakarta dengan total populasi 565 siswa. Sampel penelitian ini ditentukan dengan teknik proportional random sampling yaitu banyaknya pengambilan sampel secara proporsional dengan jumlah elemen setiap unit pemilihan sampel. Kemudian dari unit pemilihan sampel tersebut dipilih secara acak. Penentuan sampel secara random menggunakan Nomogram Harry King dengan populasi sebanyak 565 siswa dengan taraf kesalahan 5\% maka didapatkan sampel penelitian 185 siswa. Kemudian penentuan sampel secara proportional seperti yang disajikan pada Tabel 1 .

Teknik pengumpulan data variabel bebas menggunakan angket dengan skala Likert dan Rating Scale. Angket yang digunakan dalam penelitian ini adalah closed ended questioner atau kuesioner tertutup yaitu berbagai pertanyaan/pernyataan yang dibuat dengan memberikan alternatif jawaban yang telah tersedia, sehingga responden tinggal memilih pilihan jawaban sesuai kondisi sebenarnya.

Tabel 1. Perhitungan Sampel Tiap SMK

\begin{tabular}{lcc}
\hline \multicolumn{1}{c}{ Nama SMK } & $\begin{array}{c}\text { Populasi dan } \\
\text { Perhitungan Sampel }\end{array}$ & $\begin{array}{c}\text { Jumlah } \\
\text { Sampel }\end{array}$ \\
\hline SMK 2 & 104 & 34 \\
SMK 3 & $(104 / 565 \times 185)$ & \\
& 120 & 39 \\
SMK Muhammadiyah 3 & $(120 / 565 \times 185)$ & \\
& $101 / 565 \times 185)$ & 33 \\
SMK Piri 1 & 102 & 33 \\
& $(102 / 565 \times 185)$ & \\
SMK Perindustrian & 62 & 20 \\
& $(62 / 565 \times 185)$ & \\
SMK Taman Siswa & 76 & 25 \\
\hline Jumlah Total & $(76 / 565 \times 185)$ & \\
\hline
\end{tabular}

Data variabel terikat dikumpulkan menggunakan dokumentasi yaitu pengumpulan data dengan menghimpun dan menganalisis dokumen-dokumen, baik dokumen tertulis, gambar maupun elektronik. Teknik ini akan digunakan untuk menganalisis dokumen hasil belajar praktik siswa yang diambil setelah pengujian UKK Ujian Praktik Kejuruan Kelistrikan Otomotif siswa kelas XII TKR.

Analisis data pada penelitian ini menggunakan analisis data statistik. Data penelitian yang diperoleh akan dianalisis dengan statistik deskriptif dan statistik inferensial. Statistik deskriptif akan menggambarkan data yang telah terkumpul sebagaimana adanya dengan menampilkan data meliputi distribusi frekuensi, total skor, harga skor rata-rata, simpangan baku, modus, median, skor maksimum, skor minimum yang disertai dengan diagram batang. Kemudian data tersebut akan dideskripsikan dalam sebuah kriteria penilaian.

Statistik inferensial pada penelitian ini dilaksanakan dengan menganalisis data sampel yang diambil yang hasilnya diberlakukan untuk populasi yaitu menggunakan analisis regresi berganda. Sebelumnya diadakan uji persyaratan analisis antara lain uji normalitas, 
linieritas, dan multikolinieritas sebagai syarat sebelum melakukan analisis regresi berganda.

\section{HASIL PENELITIAN DAN PEMBAHASAN}

Hasil penelitian terlebih dahulu disajikan dalam bentuk deskripsi hasil penelitian bertujuan untuk memberikan gambaran umum dari penyebaran data yang diperoleh di lapangan. Data yang disajikan dari hasil penelitian ini berupa data mentah yang diolah menggunakan statistik deskripsi dengan bantuan software IBM SPSS STATISTIC 20. Deskripsi data penelitian ini meliputi distribusi frekuensi, total skor, harga skor ratarata, simpangan baku, modus, median, skor maksimum, skor minimum yang disertai dengan diagram batang.

Data hasil penelitian variabel bebas persepsi penguasaan metode mengajar praktik guru yang didapatkan melalui instrumen angket dengan jumlah sebanyak 23 butir pernyataan mempunyai nilai skor minimun 58 dan skor maksimum 107. Skor total didapatkan sebesar 16.146 , rata-rata (M) 88,74, simpangan baku (SD) 8,723, modus (Mo) 96, median (Me) 89, dan varians 76,098. Sebaran data persepsi penguasaan metode mengajar praktik guru disajikan pada Gambar 1.

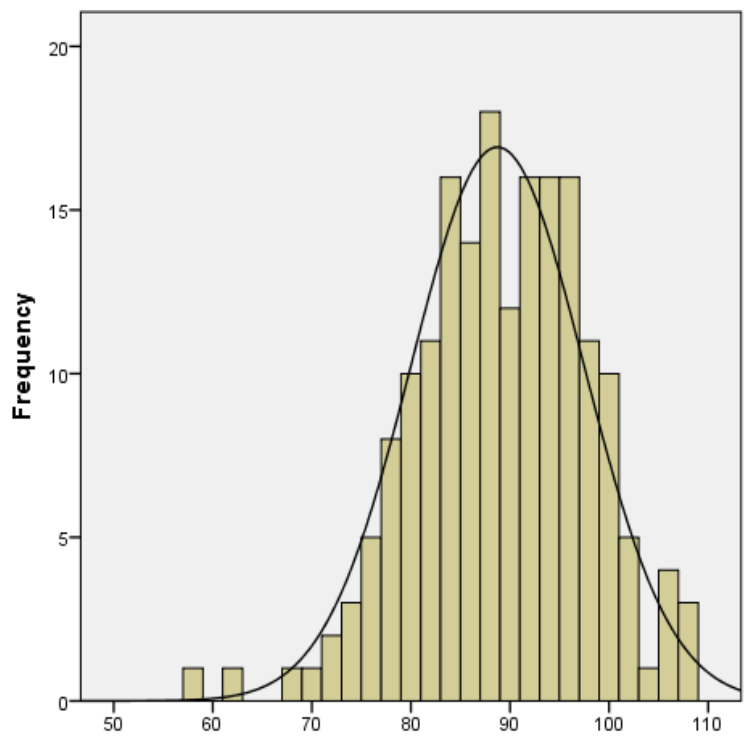

Gambar 1. Histogram Persepsi Penguasaan Metode Mengajar Praktik Guru

Data hasil penelitian variabel bebas media pembelajaran yang digunakan guru didapatkan melalui instrumen angket dengan jumlah sebanyak 21 butir pernyataan mempunyai nilai skor minimum 54 dan skor maksimum 103. Skor total didapatkan sebesar 14.171, rata-rata (M) 76,60, simpangan baku (SD) 9,613, modus (Mo) 74, median (Me) 76, dan varians 92,415 . Kemudian sebaran data media pembelajaran disajikan pada Gambar 2.

Data hasil penelitian variabel bebas motivasi belajar siswa yang didapatkan melalui instrumen angket dengan jumlah sebanyak 19 butir pernyataan mempunyai nilai skor minimum 43 dan skor maksimum 74 . Skor total didapatkan sebesar 11.026, rata-rata (M) 59,60, simpangan baku (SD) 5,873, modus (Mo) 63, median (Me) 60, dan varians 34,491. Kemudian sebaran data motivasi belajar siswa disajikan pada Gambar 3.

Data hasil penelitian variabel terikat hasil belajar siswa yang didapatkan melalui studi dokumenter mempunyai nilai skor minimum 72 dan skor maksimum 100. Skor total didapatkan sebesar 16.035, rata-rata (M) 86,68, simpangan baku (SD) 7,509, modus (Mo) 86, median (Me) 87, dan varians 56,383. Kemudian sebaran data hasil belajar siswa disajikan Gambar 4.

Kemudian pada data penelitian dianalisis secara statistik inferensial dengan analisis regresi linier berganda. Analisis regresi ini bertujuan agar dapat menemukan jawaban dari hipotesis yang telah dibuat. Hasil uji regresi linier berganda disajikan pada Tabel 2 .

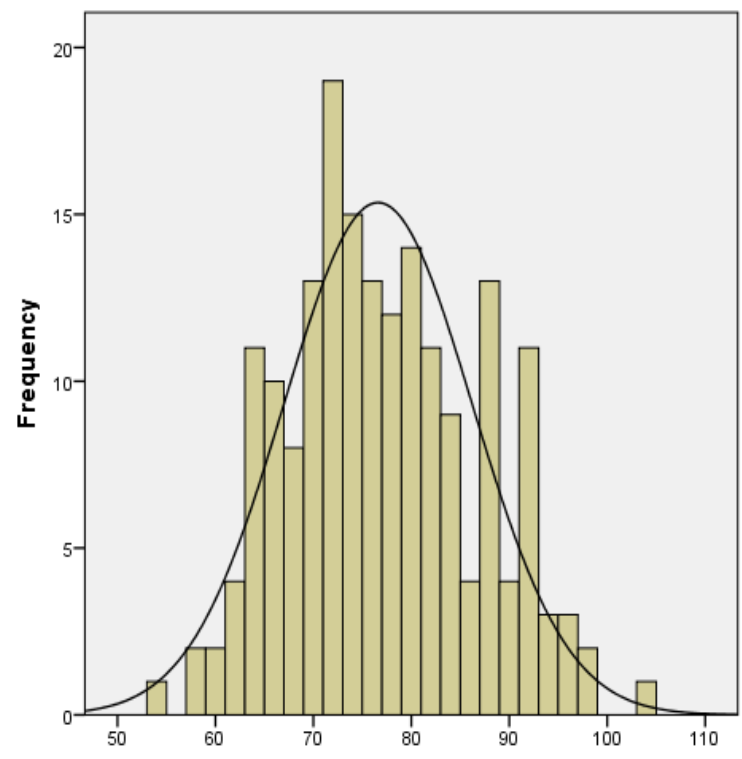

Gambar 2. Histogram Media Pembelajaran 


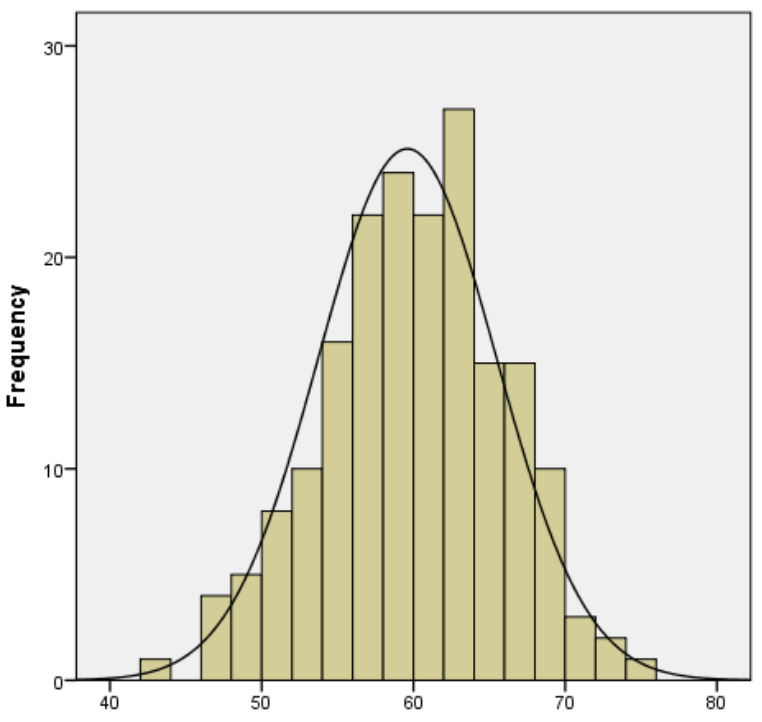

Gambar 3. Histogram Motivasi Belajar Siswa

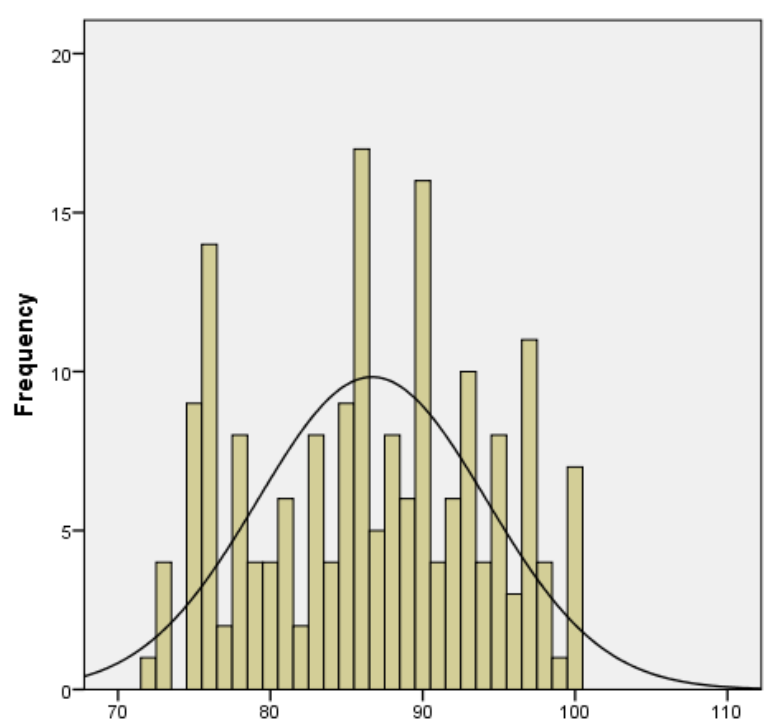

Gambar 4. Histogram Hasil Belajar Siswa

Tabel 2. Hasil Uji Regresi Linier Berganda

\begin{tabular}{lccccc}
\hline \multicolumn{5}{c}{ Var.X2 } & \multicolumn{2}{c}{$\begin{array}{c}\text { Unstandardized } \\
\text { Coefficient }\end{array}$} & & & \\
\cline { 2 - 4 } & B & Std. & T & F & Sig. \\
Error & & & \\
\hline Constant & 51,482 & 6,701 & 7,683 & 10,550 & 0,000 \\
X1 & 0,135 & 0,067 & 2,027 & & 0,044 \\
X2 & 0,139 & 0,067 & 2,082 & & 0,039 \\
X3 & 0,211 & 0,100 & 2,118 & & 0,036 \\
\hline
\end{tabular}

Hasil analisis data pengaruh persepsi penguasaan metode mengajar praktik guru
(X1) terhadap hasil belajar siswa (Y) yaitu seperti yang terlihat pada Tabel 2 menunjukkan nilai uji t hitung X1 adalah 2,027 dan nilai sig.0,044. Karena nilai sig. $0,044<(\alpha$ : $0,05)$ maka Ho ditolak dan Ha diterima. Dapat disimpulkan persepsi penguasaan metode mengajar praktik guru berpengaruh signifikan terhadap hasil belajar siswa.

Pada Tabel 2, lalu menunjukkan persamaan regresinya yaitu, $\hat{Y}=51,482+0,135$ $\mathrm{X}_{1}$. Persamaan regresi tersebut maknanya adalah apabila persepsi penguasaan metode mengajar praktik guru bertambah sebanyak 1 poin maka hasil belajar siswa akan bertambah sebanyak 0,135. Kemudian seberapa besar persentase kontribusi pengaruh yang diberikan variabel $\mathrm{X} 1$ terhadap $\mathrm{Y}$ didapatkan melalui perhitungan sumbangan efektif (SE) sehingga diperoleh nilai SE X1 sebesar 4,34\%.

Hasil penelitian tersebut membuktikan bahwa persepsi penguasaan metode mengajar praktik guru mempengaruhi hasil belajar siswa pada pembelajaran praktik kelistrikan otomotif. Pembelajaran praktik diadakan bertujuan untuk melatih dan mengembangkan keterampilan tertentu dari siswa. Ini menunjukkan wujud nyata bahwa pentingnya guru menguasai metode mengajar praktik memang dapat memberikan pengaruh nyata bagi hasil belajar. Karena guru yang hanya menjalankan pembelajaran praktik tanpa mengetahui prosedur mengajar praktik yang tepat akan sulit mencapai tujuan belajar yang diinginkan apalagi mampu mendeteksi dimana letak kesalahannya (Vargas, 2009). Berpijak pada uraian yang diungkapkan tersebut dan melihat refleksi dari hasil penelitian ini sendiri sudah cukup membuktikan bahwa pentingnya penguasaan metode mengajar praktik oleh guru memberikan dampak positif ataupun negatif bagi tercapainya hasil belajar yang diinginkan.

Hasil penelitian selanjutnya adalah hasil analisis data pengaruh media pembelajaran (X2) terhadap hasil belajar siswa (Y). Tabel 2 sebelumnya menunjukkan nilai uji thitung X2 adalah 2,082 dan nilai sig.0,039. Karena nilai sig.0,039 < $(\alpha: 0,05)$ maka Ho ditolak dan Ha diterima. Oleh karena itu, dapat disimpulkan persepsi media pembelajaran berpengaruh signifikan terhadap hasil belajar siswa.

Tabel 2, menunjukkan persamaan regresinya yaitu, $\hat{\mathrm{Y}}=51,482+0,139 \mathrm{X}_{2}$. Persamaan regresi tersebut maknanya adalah apabila media pembelajaran bertambah sebanyak 
1 poin maka hasil belajar siswa akan bertambah sebanyak 0,139. Kemudian untuk mengetahui seberapa besar persentase kontribusi pengaruh yang diberikan variabel $\mathrm{X} 2$ terhadap Y didapatkan melalui perhitungan sumbangan efektif sehingga diperoleh nilai SE X2 sebesar $5,85 \%$.

Hasil penelitian tersebut membuktikan bahwa media pembelajaran yang digunakan guru mempengaruhi hasil belajar siswa pada pembelajaran praktik kelistrikan otomotif. Pembelajaran kelistrikan otomotif yang memiliki karakter abstrak hal ini tentu akan menyulitkan bagi para siswa untuk memahaminya terutama jika dibandingkan dengan engine dan chasis yang bersifat nyata. Keterbatasan daya indera dalam menangkap informasi pada kelistrikan tidak hanya menyulitkan untuk membangun pemahaman tetapi juga mempengaruhi jangka waktu penyimpanan memori di otak. Semakin terbatas daya indera yang dapat diaktifkan dalam belajar maka akan semakin pendek memori dapat merekam dalam jangka waktu lama berbeda apabila seseorang memaksimalkan semua daya indera yang kita miliki maka memori akan merekam dengan jangka waktu yang lebih panjang (Arsyad, 2014).

Hasil penelitian selanjutnya adalah hasil analisis data pengaruh motivasi belajar siswa (X3) terhadap hasil belajar siswa (Y). Tabel 2 menunjukkan nilai uji t hitung X3 adalah 2,118 dan nilai sig.0,036. Karena nilai sig. $0,036<(\alpha: 0,05)$ maka Ho ditolak dan Ha diterima. Maka dapat disimpulkan motivasi belajar siswa berpengaruh signifikan terhadap hasil belajar siswa.

Pada Tabel 2, lalu menunjukkan persamaan regresinya yaitu, $\hat{\mathrm{Y}}=51,482+0,211 \mathrm{X}_{3}$. Persamaan regresi di atas maknanya adalah apabila motivasi belajar siswa bertambah sebanyak 1 poin maka hasil belajar siswa akan bertambah sebanyak 0,211 . Kemudian untuk mengetahui seberapa besar persentase kontribusi pengaruh yang diberikan variabel $\mathrm{X} 3$ terhadap $\mathrm{Y}$ didapatkan melalui perhitungan sumbangan efektif sehingga diperoleh nilai SE X3 sebesar $4,71 \%$.

Hasil penelitian tersebut membuktikan bahwa motivasi belajar siswa mempengaruhi hasil belajar siswa pada pembelajaran praktik kelistrikan otomotif. Motivasi dalam belajar dapat menimbulkan tingkat kepercayaan diri akan keinginan untuk berhasil yang baik
(Nolker dan Schoenfeldt, 1983). Dalam hal ini diketahui mata pelajaran kelistrikan otomotif bukanlah mata pelajaran favorit yang menjadi kesukaan siswa terutama karena tingkat kesulitannya yang cukup tinggi. Melalui tingkat motivasi yang baik maka siswa akan memiliki energi positif dalam menghadapi dan menyelesaikan hambatan-hambatan dalam mempelajari kelistrikan otomotif. Namun, apabila tingkat motivasinya sudah rendah maka akan sulit bagi para siswa untuk memahami kelistrikan otomotif bahkan jikalau guru sudah berusaha maksimal dalam mengajar mereka.

Hasil penelitian selanjutnya adalah hasil analisis data pengaruh persepsi penguasaan metode mengajar praktik guru (X1), persepsi media pembelajaran (X2), dan motivasi belajar siswa (X3) secara bersama-sama terhadap hasil belajar siswa (Y). Pada Tabel 2 menunjukkan nilai uji $\mathrm{F}$ hitung variabel persepsi penguasaan metode mengajar praktik guru (X1), persepsi media pembelajaran (X2), dan motivasi belajar siswa (X3) secara bersamasama adalah 10,550 dan nilai sig.0,000. Karena nilai sig. $0,000<(\alpha$ : 0,05) maka Ho ditolak dan Ha diterima. Oleh karena itu, dapat disimpulkan persepsi penguasaan metode mengajar praktik guru, media pembelajaran, dan motivasi belajar siswa secara bersama-sama berpengaruh signifikan terhadap hasil belajar siswa.

Tabel 2 juga menunjukkan persamaan regresi linier berganda yaitu, $\hat{Y}=51,482+$ $0,135 X_{1}+0,139 X_{2}+0,211 X_{3}$. Persamaan regresi tersebut maknanya adalah apabila persepsi penguasaan metode mengajar praktik guru bertambah sebanyak 1 poin maka hasil belajar siswa akan bertambah sebanyak 0,135 , jika persepsi media pembelajaran bertambah sebanyak 1 poin maka hasil belajar siswa akan bertambah sebanyak 0,139 . Jika motivasi belajar siswa bertambah sebanyak 1 poin maka hasil belajar siswa akan bertambah sebanyak 0,211 . Kemudian untuk mengetahui seberapa besar persentase pengaruh yang diberikan variabel $\mathrm{X} 1, \mathrm{X} 2$ dan $\mathrm{X} 3$ terhadap $\mathrm{Y}$ dapat dilihat melalui Tabel 3.

Tabel 3. Hasil R Square Regresi Linier Berganda

\begin{tabular}{cccc}
\hline R & R Square & $\begin{array}{c}\text { Adjusted } \\
\text { R Square }\end{array}$ & Std. Error \\
\hline 0,386 & 0,149 & 0,135 & 6,985 \\
\hline
\end{tabular}


Tabel 3 menunjukkan nilai $R$ Square sebesar 0,149 yang artinya persentase kemampuan variabel $\mathrm{X} 1, \mathrm{X} 2$ dan $\mathrm{X} 3$ dalam memprediksi variabel $\mathrm{Y}$ memiliki kontribusi sebesar $14,9 \%$.

Hasil penelitian tersebut membuktikan bahwa persepsi penguasaan metode mengajar praktik guru, media pembelajaran yang digunakan guru, dan motivasi belajar siswa secara bersama-sama mempengaruhi hasil belajar siswa pada pembelajaran praktik kelistrikan otomotif.

Pada penelitian ini dimana pendidik diwakili oleh penguasaan metode mengajar praktik, peserta didik diwakili oleh motivasi belajar siswa dan sumber belajar diwakili oleh media pembelajaran ini merupakan suatu kombinasi yang secara bersama-sama dapat mempengaruhi hasil belajar siswa pembelajaran praktik kelistrikan otomotif. Ketiga kombinasi ini merupakan satu set kegiatan dan kelengkapan yang membentuk suatu pembelajaran ideal. Guru yang dapat menguasai metode mengajar praktik yang baik maka guru tersebut idealnya akan dapat menumbuhkan motivasi belajar siswa terlebih dahulu terutama pada tahap persiapan sehingga para siswa sudah siap dan antusias untuk memulai pembelajaran. Siswa yang sudah termotivasi akan lebih mudah dan siap dalam menerima pelajaran yang diberikan oleh guru. Kemudian media pembelajaran yang baik akan memudahkan guru dan memiliki kemampuan untuk membangkitkan motivasi belajar siswa. Media pembelajaran yang baik artinya dapat memberikan manfaat positif baik untuk guru maupun para siswa.

\section{SIMPULAN DAN SARAN}

\section{Simpulan}

Berdasarkan hasil penelitian dan pembahasan yang telah disampaikan, dapat disimpulkan sebagai berikut. Pertama, terdapat pengaruh yang signifikan dari persepsi penguasaan metode mengajar praktik guru terhadap hasil belajar praktik kelistrikan otomotif, dengan nilai sig. $0,044<(\alpha: 0,05)$, dan kontribusi sebesar 4,34\%.

Kedua, terdapat pengaruh yang signifikan dari media pembelajaran terhadap hasil belajar pembelajaran praktik kelistrikan otomotif, dengan nilai sig. $0,039<(\alpha: 0,05)$, dan kontribusi sebesar 5,85\%. Ketiga, terdapat pengaruh yang signifikan dari motivasi belajar siswa terhadap hasil belajar pembelajaran praktik kelistrikan otomotif, dengan nilai sig. $0,036<(\alpha: 0,05)$, dan kontribusi sebesar $4,71 \%$. Keempat, terdapat pengaruh yang signifikan dari persepsi penguasaan metode mengajar praktik guru, persepsi media pembelajaran, dan motivasi belajar siswa secara bersama-sama terhadap hasil belajar pembelajaran praktik kelistrikan otomotif, dengan nilai sig. $0,000<(\alpha: 0.05)$, dan kontribusi sebesar $14,9 \%$.

\section{Saran}

Saran yang dapat diberikan berdasarkan simpulan penelitian ini adalah sebagai berikut. Pertama, pihak sekolah dapat meningkatkan kompetensi guru melalui pelatihan-pelatihan cara metode mengajar praktik yang benar agar tidak hanya kualitas materi ajar yang berkembang namun juga kualitas metode mengajar praktik guru juga dapat berkembang.

Kedua, perlu dibentuknya tim khusus yang mengelola media pembelajaran di sekolah. Tim khusus ini yang akan melakukan penelitian dan pengembangan secara berkala untuk meningkatkan kualitas media pembelajaran yang ada di sekolah mengingat perkembangan teknologi kelistrikan otomotif yang pesat. Ketiga, para guru diharapkan lebih memperhatikan motivasi intrinsik para siswa dalam menjalani pembelajaran praktik kelistrikan otomotif.

\section{DAFTAR PUSTAKA}

Arsyad, A. (2014). Media pembelajaran. Jakarta: PT. Raja Grafindo Persada.

Atkinson, Rita L., Atkinson, Richard C., Smith, Edward E., et al. (2010). Pengantar psikologi, jilid 1. (Terjemahan Dr. Widjaja Kusuma). Tangerang: Interaksara Publisher. (Buku asli diterbitkan oleh Harcourt Brace \& Company)

Bukit, M. (2014). Strategi dan inovasi pendidikan kejuruan dari kompetensi ke kompetisi. Bandung: Alfabeta.

Depdiknas. (2003). Undang-Undang RI Nomor 20, Tahun 2003, tentang Sistem Pendidikan Nasional. Jakarta: Kemdikbud. 
Depdiknas. (2009). Strategi dan arah kebijakan pembangunan pendidikan nasional tahun 2010-2014. Jakarta: Depdiknas.

Djamarah, S.B. \& Zain, B. (2013). Strategi belajar mengajar. Jakarta: PT. Rineka Cipta.

Keller, J. M. (2010). Motivational design for learning and performance the arcs model approach. London: Springer.

Leighbody, G.B., \& Kidd, D.M. (1968). Methods of teaching shop and technical subjects. New York: Delmar Publisher.

Nolker, H., \& Schoenfeldt, E. (1983). Pendidikan kejuruan: pengajaran, kurikulum dan perencanaan. (Terjemahan Agus Setiadi). Jakarta: PT. Gramedia. (Buku asli diterbitkan oleh Expert Verlag)

Pavlova, Margareta. (2009). Technology and vocational education for sustainable development empowering individuals for the future. Australia: Springer Science+Business Media B.V.

Pribadi, B. A. (2010). Model desain sistem pembelajaran. Jakarta: Dian Rakyat.

Prosser, Charles A. \& Quigley, Thos. (1950). Vocational education; in a democracy. Chicago: American Technical Society.
Sadiman, Arief, dkk. (2012). Media pendidikan pengertian, pengembangan, dan pemanfaatannya. Jakarta: Pustekkom Dikbud dan PT. RajaGrafindo Persada.

Santrock, J. W. (2012). Perkembangan masa hidup $\left(13^{\text {th }}\right.$ ed $)$ jilid 1. (Terjemahan Benedicte Widyasinta). Jakarta: Erlangga. (Buku asli diterbitkan oleh McGraw Hill)

Smaldino, Sharon E., Lowther, Deborah L., Russel, James D. (2011). Instructional technology \& media for learning teknologi pembelajaran dan media untuk belajar $\left(9^{\text {th }} e d\right)$. (Terjemahan Arif Rahman). Jakarta: Kencana. (Buku asli diterbitkan tahun 2011 oleh Pearson Education, Inc.)

Sudijono, A. (2012). Pengantar evaluasi pendidikan. Jakarta: PT. RajaGrafindo Persada.

Uno, H. B. (2014). Teori motivasi \& pengukurannya analisis di bidang pendidikan. Jakarta: PT. Bumi Aksara.

Vargas, Julie S. (2009). Behavior analysis for effective teaching. New York: Routledge.

Westwood, Peter. (2008). What teachers need to know about teaching methods. Australia: ACER Press2008. 